\title{
Model komunikasi Ideal antara Tuna Netra dan Visual Reader dalam Menonton Film
}

\author{
Cut Meutia Karolina* \\ Fikom Unpad - Jatinangor Gd.1, Lt.1, Universitas Padjadjaran \\ Jl. Raya Bandung - Sumedang Km.21, \\ Jatinangor 45363, \\ cut12001@mail.unpad.ac.id \\ Eni Maryani \\ Fikom Unpad - Jatinangor Gd.1, Lt.1, Universitas Padjadjaran \\ Jl. Raya Bandung - Sumedang Km.21 \\ Jatinangor 45363, emaryani@gmail.com \\ Dian Wardiana Sjuchro \\ Fikom Unpad - Jatinangor Gd.1, Lt.1, Universitas Padjadjaran \\ Jl. Raya Bandung - Sumedang Km.21 \\ Jatinangor 45363, d.wardiana@unpad.ac.id
}

\begin{abstract}
Bioskop Harewos as a special cinema for the audiences with visual impairments have a uniqueness. The uniqueness that replaces the role of Audio Description with individuals, known as Visual Reader. The Visual Reader is in charge of telling the visual scene of the movie being watched. The purpose of this research is to find out the obstacles experienced of the audiences with visual impairments when watching movies accompanied by the Visual Reader; knowing the barriers of Visual Reader in giving the visual description of the movie to the audiences with visual impairments; and learned about the Bioskop Harewos preparations for the Visual Reader and the audiences with visual impairments before the watching process took place. Research methods using qualitative case studies. The results of the research found that spectators of the audiences with visual impairments experienced have several obstacles when communicating with the Visual Reader in the process of watching movies at the Bioskop Harewos. The obstacles were assessed from various aspects, therefore visual message from the film was not obtained to the maximum. Visual Reader also has difficulties in narrating visual messages to the audiences with visual impairments.
\end{abstract}

Keywords : film, Audiences, Visual Impairments, Visual Reader, Cinema

*Penulis Korespondensi 


\begin{abstract}
Abstrak. Bioskop Harewos sebagai bioskop khusus tuna netra memiliki keunikan yang menggantikan peran Audio Description dengan individu, yang dikenal dengan istilah Visual Reader. Visual Reader bertugas menceritakan adegan visual film yang sedang ditonton. Penelitian ini bertujuan untuk mengetahui proses tuna netra dalam menonton film yang didampingi oleh Visual Reader; mengetahui hambatan tuna netra dalam menonton film; mengetahui hambatan Visual Reader dalam memberi narasi bagi penonton Tuna Netra; dan mengetahui mengenai persiapan Bioskop Harewos terhadap Visual Reader dan penonton Tuna Netra sebelum proses menonton berlangsung. Metode penelitian menggunakan studi kasus kualitatif. Hasil penelitian mengungkapkan bahwa penonton Tuna Netra mengalami beberapa hambatan saat berkomunikasi dengan Visual Reader dalam proses menonton film pada Bioskop Harewos. Visual Reader juga mengalami kesulitan dalam menarasikan pesan visual kepada Tuna Netra.
\end{abstract}

Kata kunci : Film, Penonton, Tuna Netra, Visual Reader, Bioskop

\section{Pendahuluan}

Perubahan paradigma disabilitas di mata dunia dan kenyataan keterbatasan fasilitas yang dialami oleh Tuna Netra di Indonesia mendorong munculnya sebuah gerakan sosial (social movement) yang digagas oleh anak muda Bandung. Gerakan ini mencoba menghadirkan sebuah media alternatif bagi Tuna Netra. Media alternatif ini dirancang untuk mewadahi para penyandang disabilitas Tuna Netra di Bandung agar dapat menikmati film sebagaimana yang dapat dilakukan orang normal pada umumnya. Kegiatan ini dilakukan melalui Bioskop Harewos.

Keunikan Bioskop Harewos terletak pada pengganti Audio Description yang tidak berupa alat atau teknologi, akan tetapi diperankan oleh individu yang dikenal dengan istilah Visual Reader. Pada proses menonton film, satu penonton Tuna Netra akan didampingi oleh satu Visual Reader. Visual Reader ini disiapkan untuk menceritakan adegan demi adegan dalam film yang sedang ditonton. Adegan yang akan diceritakan biasanya lebih kepada adegan gerak tanpa suara dan penggambaran latar/setting film yang sedang diputarkan. Visual Reader ini sendiri menjadi kunci dari bagaimana penonton Tuna Netra mampu memaknai kisah film yang sedang ditayangkan di Bioskop Harewos dengan baik. Dengan konsep Visual Reader ini pula, bioskop yang biasa senyap dan penuh konsentrasi penonton yang dikhususkan pada layar, menjadi sedikit gaduh dengan bisikan-bisikan ramai di setiap kursi penonton. Hal ini mengacu pada makna "Harewos" yang merupakan Bahasa Sunda dengan arti berbisik.

Audio Description

(AD)

didefinisikan sebagai sebuah komentar verbal yang menyediakan informasi visual bagi penonton yang tidak dapat melihat tontonan dengan sendiri, dalam kata lain penonton yang mengalami gangguan penglihatan, seperti kebutaan. Komentar verbal yang dimaksud dapat berupa penerjemahan secara langsung atau berupa rekaman. Teknologi ini sering digunakan dalam teater, ruang museum dan televisi hingga bioskop (Walczak and Fryer, 2017). Berbeda dengan teknologi Audio Description, Visual Reader adalah deskripsi audio yang diperankan oleh seorang individu untuk satu individu penonton Tuna Netra. Secara fungsi, Visual Reader memiliki kesamaan dengan deskripsi audio, yaitu sama-sama menarasikan pesan-pesan visual yang ada 
pada layar penayangan film, sehingga dapat dikatakan pula bahwa Visual Reader adalah narator visual bagi penonton Tuna Netra yang bersifat individu, bukan teknologi.

Visual Reader dapat diartikan sebagai narator aktif bagi Tuna Netra dalam menonton film dan memiliki peran penting dalam pencapaian makna film bagi Tuna Netra. Narator itu sendiri menurut KBBI adalah orang yang bercerita atau pencerita. Pada konsep Visual Reader, narator diartikan sebagai sebuah pekerjaan yang menceritakan visual film yang tidak terlihat oleh mata kepada penonton netra yang didampinginya. Pada disabilitas lain, tugas sejenis narator sudah cukup familiar, contohnya penerjemah bahasa bagi tuna rungu.

Teknologi Audio Description pada dasarnya sudah sangat familiar di beberapa negara di dunia. Beberapa negara Eropa, Australia, dan Amerika sudah mulai mengembangkan teknologi alat bantu menonton film bagi disabilitas Tuna Netra. Audio Description ini merupakan sebuah alat yang bertugas sebagai narator yang akan menjelaskan visual konten dalam bentuk kata-kata kepada para penonton Tuna Netra. Sebagaimana dilansir www.independent.uk pada 2017 (Lopez, 2017), teknologi AD ini sudah cukup berkembang dan mulai disediakan untuk penonton Tuna Netra sebagai alat bantu menonton film di beberapa bioskop di United Kingdom. Bahkan di Australia, penayangan acara di televisi sudah menyediakan deskripsi audio untuk penonton Tuna Netra. Sayangnya, teknologi ini belum hadir di Indonesia. Bioskop-bioskop di Indonesia hanya mampu menyediakan hiburan kepada masyarakat normal, tanpa ada inovasi bantuan apapun bagi kaum disabilitas, khususnya disabilitas Tuna Netra.
Film dan Tuna Netra di Indonesia, sering kali diartikan menjadi dua makna yang saling bertentangan. Anggapan orang awam tentang film yang dinilai hanya dapat dinikmati dengan melihat. Padahal keterbatasan melihat bukanlah hambatan untuk menikmati sebuah tayangan film. Tuna Netra masih bisa menikmati tayangan film meskipun dengan kondisi keterbatasan penglihatan. Menonton film juga menjadi bagian dari hak disabilitas Tuna Netra, mereka memiliki hak untuk menjadikan film sebagai bagian dari sumber informasi dan hiburan. Bahkan, pada kenyataannya banyak di antara penyandang disabilitas Tuna Netra sangat tertarik dengan keberadaan film.

Undang-undang No 33 tahun 2009 tentang perfilman Indonesia telah mengatur tentang film secara kesuluruhan. Pada UU No 33 ini juga menyebutkan tentang bagaimana film sebagai hak seluruh masyarakat tanpa ada batasan. Namun, perlindungan hukum pada hak kaum disabilitas masih begitu kurang dan lemah. Tidak ada ayat yang mengatur secara spesifik tentang pemenuhan kebutuhan disabilitas secara khusus dalam hal mengkonsumsi film. Ini akhirnya berimbas pada fasilitas bioskop yang tidak memadai untuk disabilitas terutama Tuna Netra.

Kemajuan teknologi dan perkembangan masyarakat secara global turut serta membawa perubahan pada pandangan terhadap disabilitas. Pada masa kini, pandangan tentang keberadaan disabilitas tidak lagi sama seperti pandangan masa lampau yang hanya melihat dari sisi kekurangan fisik dan mental. Disabilitas mulai dilihat dari sisi kemanusiaan dan kebutuhankebutuhannya dianggap sama dengan orang lain pada umumnya. Propiona dkk menyatakan bahwa model dan konsep disabilitas dapat dibagi menjadi 3, yaitu: (1) Konsep disabilitas sebagai model 
individualis medis; (2) konsep disabilitas sebagai model individual secara sosial dan (3) konsep disabilitas yang memandang pendekatan hak asasi manusia. Disabilitas pada masa kini cenderung dilihat dengan konsep ketiga, yakni memandang disabilitas sebagai masyarakat biasa yang memiliki hak asasi, yaitu tidak ada hubungan antara antara kelainan anatomi fisik atau mental dengan keberfungsian sosialnya kecuali disebabkan adanya tindakan deskriminasi. Namun konsep human right belum sepenuhnya dijalankan di Indonesia. (Propiona, Kurniasari, Widyawati, Rohman, \& Marzuki, 2013)

International Labour Organization (ILO) mencatat terdapat $\mathbf{1 1 . 5 8 0 . 1 1 7}$ jiwa penyandang disabilitas yang ada di Indonesia. Penyandang disabilitas Tuna Netra merupakan disabilitas terbanyak. Penyandang disabilitas Tuna Netra di Indonesia tercatat mencapai angka 3.474.035 jiwa, yaitu hampir mencapai angka 30\% dari keseluruhan. Ini bukanlah jumlah yang sedikit untuk diabaikan. Maka kebutuhan fasilitas khusus untuk mengakses berbagai hal bagi Tuna Netra menjadi sesuatu yang penting. Termasuk juga mengakses film.

Ada beberapa definisi yang mencoba menggambarkan definisi dari Tuna Netra ini. Seperti menurut Muharomah, tuna netra adalah kondisi seseorang yang dapat dikategorikan menjadi dua kategori; buta total (total blind) dan masih sisa penglihatan (low vision) (Muharomah, 2016), sedangkan Soemantri dalam (Rasyidah 2015) mengartikan Tuna Netra adalah tidak saja mereka yang mengalami kebutaan, akan tetapi juga termasuk mereka yang memiliki keterbatasan penglihatan dan kurang berfungsi untuk kepentingan hidup sehari-hari, terutama dalam belajar. Maka dari itu, menurutnya, "setengah melihat", "low vision", atau rabun, adalah bagian dari kelompok Tuna Netra. Pada penonton Bioskop Harewos, kelompok Tuna Netra dianggap sama. Penonton dengan kondisi total blind dan low vision mendapat kesempatan menonton yang sama dan diberi terjemahan yang sama pula.

Model komunikasi antara Visual Reader dan Tuna Netra pada Bioskop Harewos sangat unik. Visual Reader harus memiliki kemampuan yang baik dalam menyampaikan narasi visual kepada penonton Tuna Netra, agar Tuna Netra dapat memahami isi film dengan dukungan narasi visual yang disampaikan oleh Visual Reader. Namun pada kenyataannya, masih banyak hambatanhambatan komunikasi yang terjadi sehingga tujuan menonton film menjadi tidak tercapai dengan maksimal. Artinya, butuh banyak pembenahan agar Tuna Netra memahami isi film secara sempurna.

Antara Visual Reader dan penonton Tuna Netra membutuhkan sebuah model komunikasi yang menjadi solusi dari hambatan-hambatan komunikasi yang dirasakan. Hambatan komunikasi menurut Ruslan (2008) adalah hambatanhambatan yang terjadi karena faktor proses penyampaian, fisik, semantik, dan hambatan sosial. Pada komunikasi yang terjadi antara visual rader dan penonton Tuna Netra, hambatan yang terjadi bisa pada hambatan proses penyampaian, fisik maupun sosial.

Penelitian mengenai pengembangan komunikasi Tuna Netra dan pola komunikasi pada disabilitas sudah cukup popular dalam penelitian komunikasi. Penelitian Ganea dkk menemukan bahwa adanya perbedaan perilaku komunikasi oleh bayi dari orang tua tunanetra terhadap orang tua normal khusus untuk komunikasi dengan orang tua. Menurutnya, fleksibilitas dalam 
perkembangan awal perilaku komunikasi manusia, yang memungkinkan bayi untuk mengoptimalkan tawaran komunikatif dan metode mereka ke lingkungan sosial mereka yang unik (Ganea et al. 2018). Artinya, komunikasi yang dilakukan pada Tuna Netra dewasa tentunya akan membentuk pola yang berbeda dengan Tuna Netra di usia anak dan bayi. Selanjutnya, mengenai Tuna Netra, Shojaee dkk pernah menulis dengan judul Family communication patterns of individuals with and without disabilities. Karyanya menemukan bahwa dalam berkomunikasi dalam keluarga, tidak ada perbedaan yang signifikan antara individu dengan kebutaan dan tuli dalam hal orientasi konformitas. Hasil penelitian ini juga menunjukkan bahwa reformasi komunikasi keluarga pola sangat penting untuk individu dengan kebutaan dan ketulian (Shojaee, Khakhaninejad, and Najafi, 2018). Menurut Nurjaman, hubungan pertemanan antara orangorang tunanetra dan orang biasa berawal dari kontak yang diaktifkan oleh salah satu pihak melalui salam. Sapaan ini pada pihak tunanetra menjadi bahan untuk menghafal dan mengetahui identitas dari teman yang ditemui (Nurjaman, 2018).

Hasil penelitian terdahulu membuktikan bahwa tuna netra tentunya membutuhkan perhatian khusus dan kebutuhan khusus dalam mengakses film. Namun, dari berbagai sumber penelitian yang penulis temui, belum ada penelitian yang membahas tentang Visual Reader sebagai sebuah upaya pengadaan media yang memudahkan tuna netra dalam mengakses film. Peneliti melihat bahwa kebutuhan Tuna Netra akan film serta pembentukan model komunikasi yang ideal agar tercapainya tujuan komunikasi secara sempurna menjadi cukup penting untuk dikaji lebih dalam. Maka dari itu, pada tulisan ini mengkaji lebih dalam mengenai pengembangan Bioskop Harewos melalui Visual Reader untuk para Tuna Netra.

Penelitian ini mengkaji bagaimana model komunikasi yang ideal antara Tuna Netra dan Visual Reader untuk mencapai tujuan menonton film secara sempurna. Secara spesifik akan mengkaji tentang tuna netra dalam hal menonton film yang didampingi oleh Visual Reader; mengetahui hambatan yang dialami tuna netra selama menonton film; mengetahui hambatan Visual Reader dalam memberi narasi bagi penonton Tuna Netra; dan mengetahui mengenai persiapan Bioskop Harewos terhadap Visual Reader dan penonton Tuna Netra dalam pelaksanaan Bioskop Harewos.

Teori yang digunakan adalah teori interaksi simbolik . Interaksi simbolik merupakan salah satu perspektif teori yang muncul dari aliran sosiologi Amerika yang lahir dari tradisi psikologi. Teori interaksi simbolik berkembang pertama kali di Universitas Chicago. Beberapa tokoh teori ini diantaranya adalah John Dewey dan C. H. Cooley.

Teori interaksi simbolik menekankan pada hubungan antara simbol dan interaksi. Bagi teori ini, individu bersifat aktif, reflektif dan kreatif, menafsirkan, menampilkan perilaku yang rumit dan sulit diramalkan sehingga teori ini menganggap bahwa individu terus berubah, interaksi-lah yang dianggap sebagai variabel penting yang menentukan perilaku manusia. Teori ini berasumsi bahwa orang bertindak berdasarkan makna simbolik yang muncul di dalam sebuah situasi tertentu (West \& Turner (2007: 98). 


\section{Metode}

Penelitian ini menggunakan metode penelitian kualitatif dengan pendekatan studi kasus. Teknik pengumpulan data yang dilakukan peneliti menggunakan teknik wawancara mendalam dengan berbagai sumber, mengobservasi lapangan, dan melihat dokumen-dokumen yang terkait. Pra riset dilakukan selama kurang lebih satu bulan dan pengumpulan data penelitian menghabiskan waktu selama 5 bulan. Peneliti melakukan wawancara mendalam terhadap orangorang yang terlibat dalam penayangan Bioskop Harewos, diantaranya pada seluruh tim penggagas Bioskop Harewos yang berjumlah 3 orang, 8 orang Visual Reader dan 7 penonton tuna netra di Bioskop Harewos. Pemilihan informan wawancara dilakukan berdasarkan kebutuhan data yang mendalam dari berbagai sudut pandang pelaku yang terlibat. Peneliti mewawancarai seluruh tim penggagas untuk memperoleh data mengenai keadaan persiapan lapangan yang terjadi serta kendala-kendala dari sisi pengelola, 8 Orang Visual Reader untuk memperoleh informasi keberlangsungan Bioskop Harewos dari sisi relawan Visual Reader dan 7 penonton tuna netra untuk memperoleh data mengenai kebutuhan serta evaluasi dari sisi penonton.

Teknik analisis data yang dilakukan dalam penelitian ini adalah dengan cara deskriptif, analisis tema dan Assertions (penonjolan). Penelitian dilakukan di Bioskop Harewos, Kota Bandung, terhitung sejak November 2018 hingga Juli 2019.

\section{Hasil dan Pembahasan}

Berdasarkan data-data dari hasil wawancara mendalam dan observasi lapangan, penelitian ini memberi gambaran tentang sikap dan perilaku Tuna Netra saat menonton film dengan didampingi oleh Visual Reader, hambatan yang dialami dari sisi Visual Reader maupun penonton Tuna Netra; serta persiapan yang dilakukan para pengelola Bioskop Harewos terhadap Visual Reader dan penonton Tuna Netra sebelum proses menonton berlangsung. Penelitian mengungkapan bahwa ada hambatan komunikasi yang menyebabkan tidak tercapainya tujuan komunikasi secara maksimal antara Visual Reader dan penonton Tuna Netra.

Penelitian ini mengungkapkan bahwa penonton Tuna Netra merasa sangat membutuhkan peran Visual Reader dalam proses menonton film. Visual Reader membantu mengarahkan mereka dalam menerjemahkan isi pesan dari sebuah film yang mereka tonton. Bagi penonton Tuna Netra, Visual Reader menjadi bagian penting karena segala hal yang mereka dengar dari film dapat diperjelas atau menjadi lebih akurat melalui deskripsi pesan visual dari Visual Reader tersebut.

Penonton Tuna Netra di Bioskop Harewos termasuk penonton Tuna Netra yang unik, karena mereka sama sekali tidak pernah mengetahui atau menggunakan alat pendeskripsi film otomatis bagi Tuna Netra, atau yang sering dikenal dengan istilah teknologi Audio Description (AD). Ketidakadaan pengalaman menggunakan $\mathrm{AD}$, mengakibatkan penonton Tuna Netra di Bioskop Harewos tidak dapat membandingkan antara narasi pesan visual yang dilakukan oleh Visual Reader dengan narasi pada teknologi AD. Bagi mereka, Visual Reader sudah cukup membantu dalam pemenuhan kebutuhan terjemahan pesan visual dalam sebuah film. 
Tuna Netra mengalami perbedaan yang cukup signifikan antara menonton tanpa bantuan Visual Reader dengan menonton didampingi Visual Reader. Banyak hal yang didapatkan ketika menonton film berdampingan dengan Visual Reader. Berbeda dengan ketika menonton film sendirian, sering kali pesan-pesan visual terlewatkan dan kemungkinan kesalahan pemahaman tentang adegan flm yang terjadi. Maka dari itu, Tuna Netra berharap Visual Reader dapat hadir dalam berbagai situasi menonton. Tidak hanya untuk menonton film saja, melainkan media televisi pun mereka anggap membutuhkan sosok seperti Visual Reader. Selain itu, keberadaan Visual Reader juga dianggap sangat membantu menghindari terjadinya kesalahan pemaknaan. Misalkan dalam adegan yang hanya terdengar suara keramaian, tanpa Visual Reader Tuna Netra mengalami kesulitan membedakan suara kegaduhan karena perkelahian, suara kegaduhan karena jatuhnya barang atau kegaduhan pasar. Visual Reader hadir memberikan arahan Tuna Netra untuk berimajinasi dengan tepat.

"Saya sering tertukar
menafsirkan film yang muncul
suara gaduh, kadang mikir ini
lagi berantem atau kenapa ya.
Apa barang jatuh kenapa. Tapi
kalau didampingi oleh Visual
Reader, semuanya jadi jelas"
(Putra, 2019)

Pada Bioskop Harewos, dapat dikatakan bahwa Visual Reader berperan aktif sebagai pengganti peran Audio Description (AD) yang biasanya digunakan pada bioskop-bioskop Tuna Netra di beberapa negara Eropa dan Australia. Audio Description ini sendiri, menurut Matamala, merupakan sebuah teknologi deskriptif yang memasukkan narasi audio, penjelasan dan deskripsi pengaturan, karakter, dan tindakan yang terjadi di berbagai media audiovisual, informasi tersebut berisi tentang elemenelemen visual yang tidak ditawarkan dalam presentasi audio biasa sehingga hal-hal yang tidak dapat dilihat oleh Tuna Netra dapat dimaknai dari narasi suara (Matamala 2017). Pada bioskop Tuna Netra, fungsi Audio Description diperankan oleh Visual Reader.

Penonton film tuna netra merasa sangat terbantu dengan keberadaan pendampingan dari Visual Reader selama menonton film. Meskipun demikian, ternyata proses komunikasi dengan Visual Reader tidak berjalan dengan baik secara keseluruhan. Sebaliknya, masih ada hambatan-hambatan yang membuat proses komunikasi tidak berjalan dengan baik. Menurut penonton Tuna Netra, setiap personal Visual Reader yang ditemui memiliki cara menarasikan pesan visual secara berbeda-beda, sehingga dapat dikatakan bahwa ada Visual Reader yang mampu menyampaikan narasi sesuai dengan kebutuhan masing-masing penonton Tuna Netra, adapula yang tidak sesuai bahkan membuat suasana menonton diluar ekspektasi penonton Tuna Netra.

Menurut penonton Tuna Netra, Visual Reader yang kurang mampu menyampaikan narasi dengan baik dapat dilandasi oleh tiga alasan, yaitu Visual Reader yang melewatkan pesan visual penting untuk disampaikan ke penonton Tuna Netra, Visual Reader yang kurang komunikatif ketika menyampaikan narasi pesan visual kepada penonton Tuna Netra, dan Visual Reader yang terlalu memberikan informasi secara merinci yang dirasa tidak dibutuhkan oleh Tuna Netra juga dianggap kurang efektif. Ketiga hal ini berdampak pada rasa tidak nyaman dan kurang menikmati film yang ditonton oleh penonton Tuna Netra. 
Visual Reader yang mampu menyampaikan narasi dengan baik menurut penonton Tuna Netra adalah mereka yang mampu membangun komunikasi dengan baik dengan penonton Tuna Netra, memahami kebutuhan narasi dari Tuna Netra dan tidak terburu-buru dalam memberikan narasi. Dengan demikian, proses komunikasi antara Visual Reader dan Tuna Netra dinilai menyenangkan dan nyaman bagi penonton Tuna Netra.

Penonton Tuna Netra mengakui bahwa ada beberapa pesan visual yang dibutuhkan untuk dinarasikan oleh Visual Reader dalam menonton film. Tidak semua hal yang dilihat oleh Visual Reader harus dinarasikan kepada penonton Tuna Netra yang didampingi. Pesan visual yang dibutuhkan adalah pesan-pesan yang dianggap penting dan dapat menjadi informasi pendukung bagi Tuna Netra dalam menerjemahkan isi film. Berdasarkan wawancara terhadap penononton tuna netra terungkap lima pesan visual yang dianggap penting bagi penonton Tuna Netra untuk dinarasikan secara umum, diantaranya adalah Ciri tokoh yang muncul, Lokasi, Cuaca, Suasana, dan Jumlah tokoh yang muncul.

Pada ciri tokoh yang muncul, penonton Tuna Netra merasa bahwa informasi mengenai nama tokoh, jenis kelamin, perkiraan usia, perawakan tokoh (misalkan cantik atau tampan), dan warna pakaian dari tokoh menjadi penting disampaikan. Dengan narasi visual ini, penonton Tuna Netra dapat dengan mudah menggambarkan tokoh yang muncul dalam pikiran mereka. Selain itu, jumlah tokoh yang muncul pada frame yang sedang tampil di layar memberi kemudahan kepada Tuna Netra untuk memahami sumber suara yang muncul. Lokasi kejadian pada latar film serta cuaca dan suasana seperti keramaian, sepi, atau berkabung menjadi informasi penguat bagi Tuna Netra untuk mendalami isi film yang di tonton.

Pada umumnya penonton Tuna Netra dan Visual Reader mengaku bertemu dan berinteraksi langsung pertama kalinya di hari kegiatan menonton film di Bioskop Harewos. Pada seminggu sebelum proses menonton film sebagian besar dari mereka hanya melakukan perkenalan secara virtual (via media WhatsApp) antara kedua belah pihak. Hal ini menjadi alasan bagi Tuna Netra yang merasa tidak dapat menjalin komunikasi yang baik dengan Visual Reader yang mendampingi mereka. Perkenalan yang masih baru seringkali menimbulkan kecanggungan dalam komunikasi diantara penonton tunanetra dan Visual Reader. Ini menjadi salah satu hambatan keterbukaan penonton Tuna Netra kepada Visual Reader mengenai kebutuhan mereka. Banyak yang mereka butuhkan akan tetapi tidak disampaikan Visual Reader. Implikasi hal tersebut menyebabkan Visual Reader tidak terlalu mengetahui kebutuhan penonton Tuna Netra yang didampingi tentang pesan visual yang perlu dinarasikan. Masalah lain yang dirasakan penonton Tuna Netra adalah jika mereka sering mendapatkan Visual Reader yang baru setiap mereka menonton film di Biosklop Harewos.

Mengenai genre film yang ditonton, penelitian menemukan bahwa penonton Tuna Netra menganggap bahwa genre drama keluarga dan romansa percintaan adalah genre yang paling mudah diterima narasinya dari Visual Reader. Pada film genre romansa percintaan dan drama keluarga, pesan-pesan visual yang dibutuhkan diterjemahkan dengan baik pada sebagian besar Visual Reader. Sebaliknnya, genre thriller dan horor merupakan film yang paling sulit dipahami narasinya berdasarkan pesan 
visual dari Visual Reader. Penonton Tuna Netra merasa bahwa narasi visual dari Visual Reader pada kedua genre ini kurang membantu dalam membangun imajinasi suasana film yang mereka tonton. Selain itu, ketika Visual Reader mengalami sensasi kejut pada tayangan film yang mereka tonton, hal itu akan mengakibatkan penyampaian narasi pesan visual pada Penonton Tuna Netra seringkali terlambat, sehingga narasi yang diterima Penonton Tuna Netra tidak sesuai dengan "momentnya".

Terdapat beberapa hambatan proses menonton di Bioskop Harewos yang diungkapkan oleh Penonton Tuna Netra. Hambatan terjadi ketika saat jadwal menonton yang telah disepakati dengan Visual Reader akan tetapi saat yang sama Penonton Tuna Netra merasa mengantuk. Hal ini menyebabkan narasi visual yang disampaikan Visual Reader tidak dapat ditangkap dengan baik. Beberapa alasan lainnya adalah Penonton Tuna Netra kurang tertarik dengan film yang ditayangkan oleh Bioskop Harewos; Penonton Tunaetra dalam kondisi kelelahan karena aktivitas hari sebelumnya; dan adanya perasaan atau penilaian negatif yang dimiliki Penonton Tuna Netra terhadap sikap atau perilaku Visual Reader yang mendampinginya.

Visual Reader turut mengungkapkan hambatan-hambatan yang mereka rasakan dari perspektif mereka. Proses narasi visual tidak akan berjalan baik ketika Visual Reader merasa sulit menjalin hubungan baik penonton yang didampinginya. Hambatan juga terjadi ketika Visual Reader tidak mampu memahami kebutuhan narasi pesan visual yang dibutuhkan oleh Penonton Tuna Netra. Selain itu, Visual Reader juga mengungkapkan kesulitan saat menghadapi Tuna Netra yang mengantuk atau kelelahan.

Keterlibatan Visual Reader untuk bergabung dengan Bioskop Harewos didasarkan kerelawanan, maka seleksi yang dilakukan hanya didasarkan pada seleksi administratif. Oleh karena itu, kompetensi Visual Reader seringkali juga sangat terbatas termasuk kompetensinya dalam komunikasi. Selain masalah kompetensi komunikasi, keterbatasan Visual Reader dalam membangun hubungan dengan Tuna Netra juga terjadi dilatarbelakangi oleh kenyataan bahwa terdapat Visual Reader yang baru pertama kali berinteraksi dengan Tuna Netra. Fenomena minat untuk menjadi visual Reader menurut pengakuan pengelola sangat banyak. Hal ini menyebabkan Bioskop Harewos menerapkan sistem seleksi yang mengutamakan Visual Reader yang belum pernah terlibat. Sistem tersebut pada umumnya mengecewakan Penonton Tuna Netra karena mereka sering mendapat Visual Reader yang berganti-ganti.

Berdasarkan hasil penelitian, peneliti menemukan beberapa kompetensi yang harus dimiliki oleh Visual Reader agar mencapai tujuan komunikasi dengan baik dalam proses mendampingi Tuna Netra menonton di kegiatan Bioskop Harewos. Beberapa kompetensi tersebut dapat dilihat melalui tabel berikut: 
Tabel 1. Kompetensi Visual Reader

\begin{tabular}{|c|c|c|}
\hline No & Kompetensi & Komponen \\
\hline 1. & $\begin{array}{l}\text { Kemampuan Komunikasi } \\
\text { antarpersonal }\end{array}$ & $\begin{array}{l}\text { - Membangun hubungan yang baik dengan lawan bicara } \\
\text { - Memahami kebutuhan penonton Tuna Netra yang } \\
\text { didampingi } \\
\text { - Mengelola komunikasi dengan Tuna Netra } \\
\text { - Mengkomunikasikan perasaan dengan baik } \\
\text { - Membangun empati }\end{array}$ \\
\hline 2. & $\begin{array}{l}\text { Kemampuan mengenal disabilitas } \\
\text { Tuna Netra }\end{array}$ & $\begin{array}{l}\text { - Mengetahui jenis-jenis kerusakan penglihatan pada Tuna } \\
\text { Netra } \\
\text { - Mengetahui cara menuntun Tuna Netra dengan baik saat } \\
\text { berjalan } \\
\text { - Mengetahui cara berkomunikasi dengan Tuna Netra } \\
\text { dengan baik } \\
\text { - Mengetahui penggunaan bahasa yang tepat untuk Tuna } \\
\text { Netra } \\
\text { - Mengetahui kebutuhan narasi visual dari Tuna Netra }\end{array}$ \\
\hline 3. & Kemampuan bercerita & $\begin{array}{l}\text { - Menjelaskan pesan visual dengan cara menarik } \\
\text { - Mengatur jeda penyampaian narasi } \\
\text { - Tidak berbelit-belit }\end{array}$ \\
\hline
\end{tabular}

Sumber : Hasil Penelitian, 2019

Dengan adanya kompetensi sesuai yang dijelaskan pada tabel 1, seorang Visual Reader dipercaya kompeten dan mampu memberikan narasi visual sesuai dengan yang diharapkan. Kompetensi diatas juga memungkinkan untuk menjadi standard jika Visual Reader menjadi sebuah pekerjaan professional di kemudian hari.

Mengenai hambatan serta prediksi kesulitan yang akan terjadi dalam menonton film, tim Bioskop Harewos sendiri mencoba membuat beberapa antisipasi serta persiapan menghadapi hari menonton film. Salah satunya adalah melalui pengadaan kegiatan pertemuan dengan para Visual Reader di seminggu sebelum kegiatan menonton berlangsung. Kegiatan ini disebut dengan istilah technical meeting. Pada technical meeting tim Bioskop Harewos memberikan gambaran tentang kegiatan yang akan dilaksanakan pada hari menonton film, membagi kelompok, memperkenalkan tentang Tuna Netra secara umum dengan mendatangkan beberapa perwakilan Tuna Netra, membagi kontak penonton Tuna Netra yang akan didampingi oleh Visual Reader, dan memberikan masukan untuk setiap kelompok agar mengadakan pertemuan kelompok di hari sebelum kegiatan menonton film dilakukan.

Peneliti melihat bahwa kegiatan pertemuan seminggu sebelum kegiatan menonton dilakukan ini tidak begitu efektif. Mengingat beberapa Visual Reader yang tidak ikut mempelajari interaksi awal dengan tuna netra. Selain itu, peneliti juga menemukan bahwa pertemuan yang hanya diwakili oleh beberapa Tuna Netra saja tidak begitu mempresentasikan kebutuhan Tuna Netra secara keseluruhan. Kegiatan pertemuan kelompok yang disarankan pada beberapa hari sebelum hari menonton film juga masih berjalan tidak kondusif, beberapa kelompok masih ada yang tidak melaksanakan pertemuannya, sehingga dihari menonton film adalah pertemuan pertama kali antara Visual Reader dan 
penonton Tuna Netra di Bioskop Harewos.

Dari hasil penelitian, peneliti menemukan model komunikasi yang ideal yang sebaiknya diterapkan di Bioskop Harewos, khususnya komunikasi antara Visual Reader dengan penonton Tuna Netra. Model tersebut dapat dilihat dari gambaran berikut:

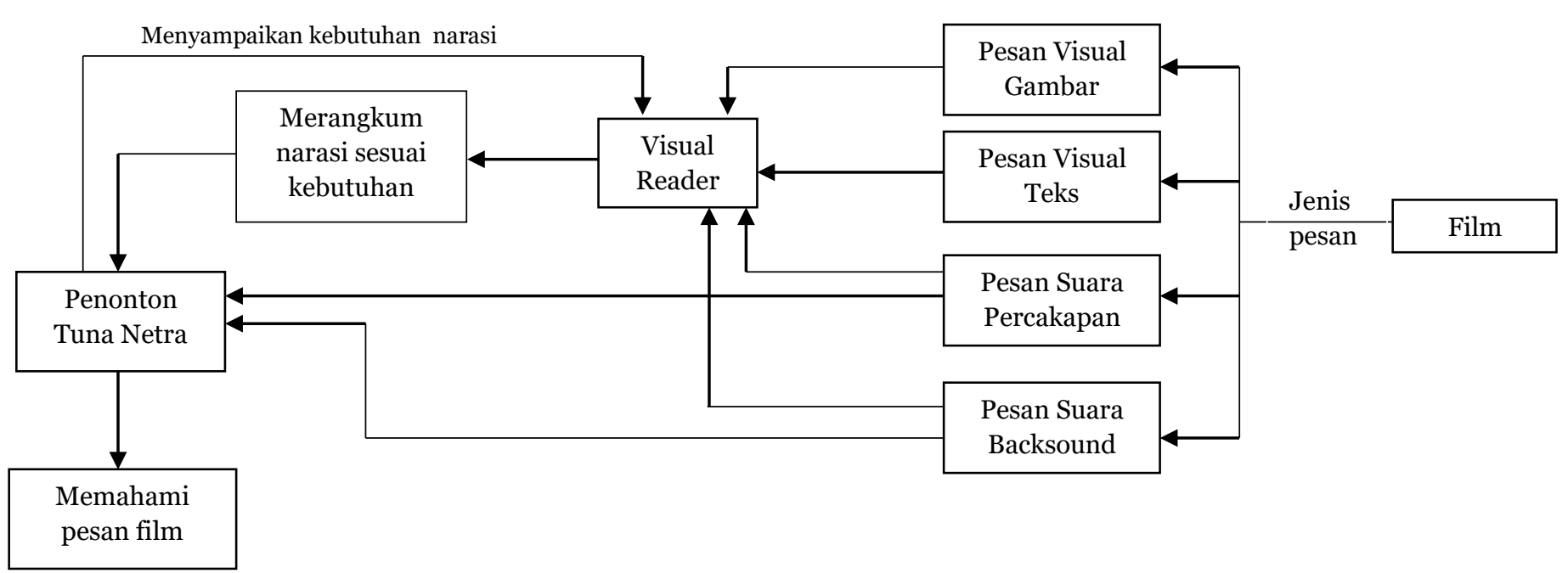

Gambar 1.Model Ideal Komunikasi Komunikasi Antara Visual Reader dan Penonton Tuna Netra Pada Proses Menonton Film

Sumber : hasil penelitian, 2019

Dari gambar 1, dapat dilihat bahwa komunikasi Visual Reader dalam menyampaikan pesan visual kepada Tuna Netra diawali dari adanya penerimaan pesan dari film kepada Visual Reader. Pesan itu sendiri dapat dibagi menjadi empat jenis pesan, yiatu (1) Pesan visual gambar; (2) Pesan visual teks; (3) pesan suara percakapan; (4) pesan suara backsound. Selanjutnya, Visual Reader juga mendapatkan informasi seputar kebutuhan narasi yang diinginkan oleh penonton Tuna Netra yang didampinginya. Melalui pesan film dan informasi kebutuhan narasi dari penonton Tuna Netra, Visual Reader merangkum dan menyesuaikannya hingga terbentuklah pesan yang baru dan disampaikan dalam bentuk narasi ke penonton Tuna Netra. Sebelum memaknai film, penonton Tuna Netra tidak hanya mengandalkan narasi dari Visual Reader, ia juga mendapatkan stimulus pesan dari film berupa pesan-pesan suara percakapan dan pesan suara berbentuk backsound. Namun, pesan-pesan yang didapatkan tidak bersifat komplit, karena tidak seluruhnya pesan dari film dapat diindrai oleh penonton Tuna Netra. Melalui pesan dari Visual Reader dan pesan film yang dapat dicerna, akhirnya Tuna Netra dapat memaknai isi film yang ada.

\section{Penutup}

Berdasarkan sub bab hasil dan pembahasan, penelitian ini dapat disimpulkan kedalam tiga hal yaitu; sikap dan perilaku Tuna Netra saat menonton film dengan didampingi oleh Visual Reader; hambatan yang dialami dari sisi Visual Reader maupun penonton Tuna Netra; serta persiapan yang dilakukan para pengelola Bioskop Harewos terhadap Visual Reader dan penonton Tuna Netra sebelum proses menonton berlangsung. 
Penonton tuna netra menganggap bahwa keberadaan Visual Reader merupakan solusi yang sangat mereka butuhkan dalam menonton film. Tuna Netra mengalami perbedaan yang cukup signifikan antara menonton tanpa bantuan Visual Reader dengan menonton didampingi Visual Reader. Banyak hal yang didapatkan ketika menonton film berdampingan dengan Visual Reader. Berbeda dengan ketika menonton film sendirian, sering kali, pesan-pesan visual terlewatkan dan kemungkinan kesalahan pemahaman tentang adegan flm yang terjadi. Maka dari itu, Tuna Netra berharap Visual Reader dapat hadir dalam berbagai situasi menonton. Tidak hanya untuk menonton film saja, melainkan media televisi pun mereka anggap membutuhkan sosok seperti Visual Reader.

Penelitian mengungkapkan ada beberapa hambatan komunikasi yang dinilai dari sisi penonton Tuna Netra, diantaranya ; hambatan dari Visual Reader yang melewatkan pesan visual penting untuk disampaikan ke penonton Tuna Netra; hambatan dari Visual Reader yang kurang komunikatif ketika menyampaikan narasi pesan visual kepada penonton Tuna Netra; hambatan dari Visual Reader yang terlalu memberikan informasi secara merinci yang dirasa tidak dibutuhkan oleh Tuna Netra; dan hambatan merasa mengantuk saat menonton film di dampingi oleh Visual Reader.

Hambatan komunikasi juga dinilai dari sisi Visual Reader dalam memberi narasi bagi penonton Tuna Netra. Penelitian menemukan beberapa hambatan yang dirasakan oleh Visual Reader dalam menarasikan isi film kepada penonton Tuna Netra, diantaranya; hambatan berkomunikasi; hambatan menjalin hubungan dengan baik; hambatan dalam mengetahui kebutuhan narasi pesan visual yang dibutuhkan oleh penonton Tuna Netra; dan hambatan menghadapi Tuna Netra yang mengantuk.

\section{Persiapan Bioskop Harewos} terhadap Visual Reader dan penonton Tuna Netra sebelum proses menonton berlangsung dilakukan melalui kegiatan technical meeting dan pembagian Visual Reader dan penonton Tuna Netra pada kelompok-kelompok kecil. Pada technical meeting tim Bioskop Harewos memberikan gambaran tentang kegiatan yang akan dilaksanakan pada hari menonton film, membagi kelompok, memperkenalkan tentang Tuna Netra secara umum dengan mendatangkan beberapa perwakilan Tuna Netra, membagi kontak penonton Tuna Netra yang akan didampingi oleh Visual Reader, dan memberikan masukan untuk setiap kelompok agar mengadakan pertemuan kelompok di hari sebelum kegiatan menonton film dilakukan.

Peneliti menyarankan beberapa solusi yang dapat dilakukan oleh tim Bioskop Harewos dalam meningkatkan kualitas Visual Reader serta meningkatkan pencapaian tujuan komunikasi antara Visual Reader dan Tuna Netra. Diantaranya adalah; (1) dalam memilih pendaftar Visual Reader, pertimbangan kualifikasi kemampuan komunikasi perlu dipertimbangkan, dalam hal ini Bioskop Harewos dapat menambah seleksi wawancara; (2) Pada formulir pendaftaran, perlu dimasukkan pengalaman khusus dibidang komunikasi kepada calon Visual Reader yang mendaftar; (3) Bioskop Harewos juga perlu mengadakan pelatihan komunikasi kepada Visual Reader yang terpilih, khususnya pelatihan penyampaian narasi visual. Pelatihan ini dapat dijadikan salah satu materi pada kegiatan pertemuan pra 
menonton yang biasanya dilakukan seminggu sebelum kegiatan menonton; (4) Bioskop Harewos juga perlu mendatangkan tim yang ahli dibidang disabilitas Tuna Netra, sehingga ada kejelasan mengenai cara yang baik berintraksi dengan disabilitas Tuna Netra dengan baik; (5) Pada technical meeting disarankan untuk menghadirkan seluruh penonton Tuna Netra, tidak hanya diwakili oleh beberapa orang saja. Sehingga perkenalan dapat dilakukan sejak awal pertemuan, dan dapat membangun kedekatan seminggu sebelum kegiatan menonotn berlangsung; (6) Film dengan genre horror dan thriller memnbutuhkan kualifikasi Visual Reader yang khusus, yaitu yang tertarik pada genre film ini. Dan (7) pada saat membuka pendaftaran bagi penonton Tuna Netra, perlu diinformasikan jenis film yang akan ditayangkan, agar sesuai dengan interest dari penonton Tuna Netra yang mendaftar.

\section{Daftar Pustaka}

Ganea, Nataşa, Kristelle Hudry, Angélina Vernetti, Leslie Tucker, Tony Charman, Mark H. Johnson, and Atsushi Senju. (2018). "Development of Adaptive Communication Skills in Infants of Blind Parents." Developmental Psychology 54 (12): 2265-73. https://doi.org/10.1037/devoooo5 64.

International Labour Organization. (2013). Inklusi Penyandang Disabilitas di Indonesia. Jakarta: ILO

Lopez, Maria. (2017). "How a New Technology Will Help Blind People 'see' at the Cinema." Independent News, $30 \quad$ November 2017. https://www.independent.co.uk/n ews/new-app-technology-helpsblind-people-see-at-cinema-audiodescription-a8072021.html. Diakses 20 May, 2019

Matamala, Anna. (2017). "Standarising Audio Description," no. July 2013.
Muharomah, Siti. (2016). "Penggunaan Bahasa Pada Anak Tunanetra: (Pengamatan Terhadap Anak Tunanetra Melalui Proses Penalaran Dalam Kegiatan Tari di Panti Sosial Bina Netra Cahaya Bathin)" Deiksis, o8 (02): 135-46. https://doi.org/ http://dx.doi.org/10.30998/deiksis.v 8io2.721.

Nurjaman, Tabah Aris. (2018). "Exploring the Interdependence Between Visually Impaired and Sighted People in the Early Phase of Friendship." IJDS: Indonesian Journal of Disability Studies 5 (1): 115-26. https://doi.org/10.21776/ub.ijds.201 8.005.01.13.

Propiona, J. K., Kurniasari, T. W., Widyawati, N., Rohman, M. S., \& Marzuki, M. A. (2013). Hak Kesehatan dan Jaminan Sosial Bagi Penyandang Disabilitas. Jakarta: Lembaga Penelitian Pengetahuan Indonesia (LIPI). 
Rasyidah, Afif Nur. (2015). "Kepercayaan Diri Pada Tuna Netra (Studi Kasus Pengguna Ilmu Getaran Perguruan Pencak Silat Beladiri Tangan Kosong Merpati Putih)." Jurnal Indigenous 13 (1): 51-59. https://doi.org/ https://doi.org/10.23917/indigenous. v13i1.2323.

Ritzer G, Douglas JG. (2010). Teori Sosiologi Modern. Jakarta: Kencana.

Ruslan, Rosady (2008). Manajemen Public Relations \& Media. Jakarta : PT. Rajagrafindo

Shojaee et Al. (2018). Family Communication Patterns in individulas with and without disabilities.
Soeprapto, Riyadi (2002). Interaksi Simbolik, Perspektif Sosial Modern. Yogyakarta: Averrpes Press.

Walczak, Agnieszka, and Louise Fryer. (2017). "Creative Description: The Impact of Audio Description Style on Presence in Visually Impaired Audiences." British Journal of Visual Impairment 35 (1): 6-17. https://doi.org/10.1177/0264619616 661603.

Wawancara dengan Putra, Penonton Tuna Netra Bioskop Harewos di PSBN Wiyataguna Bandung. (2019, Maret 29).

West, Richard and Lynn H. Turner (2007). Introducing Communication Theory : New York: Mc Graw Hill 